\title{
EXPERIMENTAL INVESTIGATION ON SHEAR STRENGTH OF ARTIFICIALLY FROZEN C - PHI SOIL
}

\author{
Gouri Mohan L \\ Associate Professor, Dept of Civil Engineering, \\ Bishop Jerome Institute, Kollam. India \\ Dr. K. K. Abdul Rasheed \\ Retd. Former Professor \& Head, Dept of Mechanical Engineering \\ TKM College of Engineering, Kollam, India \\ Dr. Reebu Zachariah Koshy \\ Professor \& Head, Dept of Civil Engineering, \\ Saintgits College of Engineering, Kottayam, India
}

\begin{abstract}
Artificial Ground Freezing $(A G F)$ is a construction technique which has been in practice for over a century, mainly in the cold regions of the world. AGF is considered as a ground improvement technique which can improve the site conditions for various civil engineering projects. It is typically used for ground stabilization and ground water control for wide variety of applications in all soil types. In-depth knowledge of the frozen soil characteristics through experiments and the development of suitable constitutive models that suit the geological conditions of our country are necessary to predict the strength and behaviour of the frozen soils. The strength and mechanical behaviour of this material can be determined experimentally and can be even predicted numerically. As this technology is not yet explored in our country an apparatus to test the strength of frozen soil in the triaxial condition is not yet developed in the laboratory. As part of this study a triaxial compression apparatus is designed and fabricated to test frozen soil samples incorporating the features of the existing triaxial apparatus on the basis of the reviewed literature and hence determining the shear parameters and strength of C-Phi soil. A more precise strength comparison between the frozen and unfrozen soil sample is done effectively in this investigation.
\end{abstract}

Keywords: Artificial Ground Freezing, C-phi soil, Frozen soil, stress strain relationship, Triaxial test setup

Cite this Article: Gouri Mohan L, Dr. K. K. Abdul Rasheed and Dr. Reebu Zachariah Koshy, Experimental Investigation on Shear Strength of Artificially Frozen C - Phi Soil, International Journal of Advanced Research in Engineering and Technology, 10(3), 2019, pp. 47-56.

$\mathrm{http}: / /$ iaeme.com/Home/issue/IJARET?Volume=10\&Issue $=3$ 


\section{INTRODUCTION}

Artificial Ground Freezing is a soil stabilization method which can be suggested when other soil improvement methods are considered infeasible. Majority of its current day application is in underground areas. The mechanical properties of frozen ground are the vital parameters in the design and implementation of AGF in underground projects. In this technique, the in-situ soil is temporarily frozen by artificially withdrawing heat from the soil with the objective of improving soil properties [1]. AGF increases the shear strength of the soil in addition to decreasing the permeability and settlement of the soil. In certain situations, this becomes the only way possible and hence its analysis and design are very significant [2]. A learning of strength and deformation of frozen soil help to foresee the situations under which a structure may fail or will help in recognizing the situation when the frozen soil is put in danger to excessive deformation. Thorough examination in this area will help in introducing this technique to practical geo-technical engineering applications. An exhaustive experimental investigation to study the compressive strength of frozen soil will pave the way to use this technology in areas where it is most appropriate and inevitable [3].

Many researchers have studied AGF and its effects on soil properties and mechanical behaviour of frozen soils [4]. But compared to unfrozen soils a greater effort is required to study frozen soils. Although AGF has been used for more than a century, there are only limited publications concerning physical properties and mechanical behaviour of frozen soils. In addition, the use of AGF as a soil supporting system is gradually increasing in underground engineering applications. More research into this area will unwrap areas of application where this technology can be applied with much ease in suitable situations compared to other existing techniques.

A thorough knowledge of the geotechnical characteristics of soils in the frozen state through a detailed experimental investigation and the development of a suitable constitutive model is necessary to predict the strength and behaviour of frozen soils [5].

\subsection{Type of Ground Freezing Techniques}

AGF involves circulating refrigerated liquid through a series of subsurface pipes to freeze the ground temporarily around the zone of excavation until the work is completed. This is mainly time-consuming process, based on time constraint freezing can be done in two ways either using calcium chloride or by using liquid nitrogen.

Brine freezing is a closed circulation system using refrigeration plants. The brine (usually calcium chloride $\mathrm{CaCl}_{2}$ ) is warmed up during circulation. The warmed-up brine flows back through the insulated surface manifold system for recooling before returning to the freeze plant station. Presently, ammonia is used as a cooling agent within the freeze unit (not as coolant in the freeze pipe system). Ammonia can be considered to be more environmentally friendly than hydrocarbon fluoride. In liquid nitrogen freezing heat is extracted from the soil through direct vaporization of a cryogenic fluid $\left(\mathrm{LN}_{2}\right)$ in the freeze pipes. The $\mathrm{LN}_{2}$ is fed through an insulated surface manifold system, usually consisting of copper pipes and quick connect cryogenic hoses, into the inner pipes from an on-site storage tank or directly from a tank truck.

\section{LABORATORY SETUP FOR ARTIFICIAL SOIL FREEZING}

To study the mechanical properties of the frozen soil an apparatus is to be designed and fabricated, as there is no existing equipment available to do the testing of this new material [6]. Triaxial tests can be conducted at different conditions of sub-zero temperature and confining pressure [7]. Proper instrumentation of the triaxial cell and the use of data acquisition system will ensure accuracy and reliability of results obtained [8]. The application 
of confining pressure allows the stress conditions found at greater depths to be modelled. Confining pressure is applied as in hydrostatic compression tests and once it is stabilized deviatoric stress is applied such that $\sigma_{1}>\sigma_{2}=\sigma_{3}$. Then stress strain curves are plotted from which the strength of the specimen can be determined. The block diagram of the components included in the newly fabricated triaxial test system to conduct investigation on frozen soil samples is shown in the Fig 1.

Due to its limited and specific applications, triaxial compression apparatus for frozen soils is not readily available in the market. For this study, a stress controlled triaxial compression apparatus was designed and manufactured to suit the present laboratory conditions [9]. Thus, the newly fabricated triaxial test system consist of following units

\subsection{Refrigeration Unit}

This unit comprises of mainly two freezers, (i) Deep freezer to freeze the soil and (ii) Liquid freezer for the freezing of the coolant to be used later.

Deep freezer is a specially designed to freeze soil specimens. It has a capacity to freeze three specimens at a time and can freeze the specimen to a maximum temperature of $-40{ }^{\circ} \mathrm{C}$. The specimen that acquired the desired temperature for the test is jacketed with a neoprene membrane which sticks firmly to the frozen soil sample. This will reduce heat transfer from the specimen and also provide a clear surface to stick the strain gauges.

Ethylene glycol is the liquid used in this test to apply confining pressure to the specimen as the freezing point of it is very low. This cooling unit is fabricated specially to cool the liquid to the required temperature as the specimen so that the desired temperature can be maintained at the time of testing the specimen.

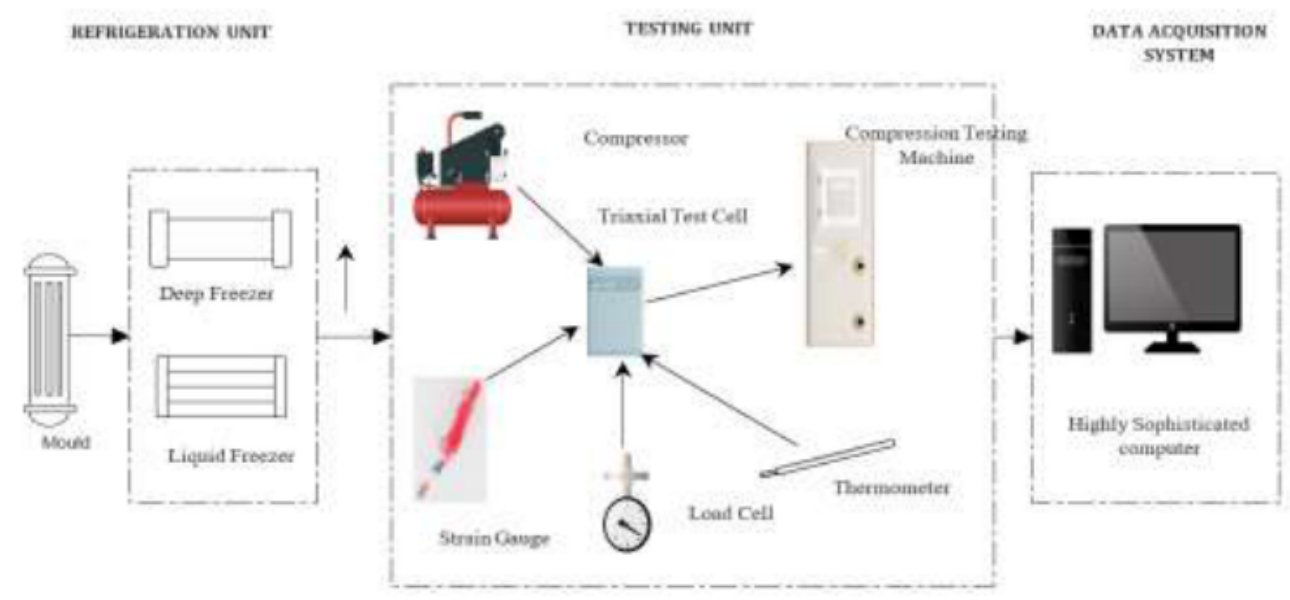

Figure 1 Schematic of new Triaxial Test System

\subsection{Testing Unit}

Testing units comprises of the following units to record the values accurately. A compressor is used in this testing unit for supplying confining pressure on the liquid coolant- Ethylene glycol. This pressure is maintained constantly throughout the test to get confining pressure [10]. Compressor is continuously monitored throughout the test so that no fluctuation in confining pressure shall be recorded.

The triaxial test cell is made of mild steel plate with dimensions of the rectangular cell being $17.5 \times 22 \times 26.5 \mathrm{~cm}$. An inlet and outlet valve are provided on either side of the test cell to supply and drain the coolant at varying temperatures. Another valve is provided to apply pressure from an external source so that it acts as confining pressure on the specimen. A 
safety valve is provided additionally to control the excess pressure. A pressure gauge is also fixed on the test cell to record the applied pressure. A plunger is provided to apply compressive load in the vertical direction. Once the confining pressure is steady; then the deviatoric load is applied on the specimen by placing the whole setup in the compression testing machine and the data is acquired to plot the stress strain curve. In order to provide proper insulation to the test setup to reduce heat transfer, glass wool packing is provided externally and nitryl rubber is provided in the inner wall of the test cell. Precooling the test set up which is properly insulated before the final test will help to maintain the desired temperature required for the test. Lead wires from the strain gauges are connected to the strain indicator by soldering through a connector.

Stain gauge is a used to measure the strain on soil sample. The gauge is attached to the sample by suitable adhesive. As the sample gets deformed the strain in the sample get recorded for a specific interval of time. The interval of time is adjusted as per the requirement. National Instruments (NI) 10 channel strain indicator with data acquisition system using LAB VIEW software is used.

An Ultra Compact Lightweight Compression Load Cell of capacity $10 \mathrm{kN}$ is used for measuring the load distribution during testing of the frozen soil specimen at various temperatures and pressures. The load cell is placed centrally above the plunger of the apparatus for applying load to the specimen. The load is then uniformly applied with the help of the Compression Testing Machine at a constant stress rate. The load cell is connected to the strain channel indicator and the data are captured by data acquisition system using LabVIEW Software at specified intervals.

An infra-red thermometer is used to ensure the temperature within the sample during the testing procedure. Thermometer readings are checked at regular intervals and temperature within the samples are ensured.

Once the confining pressure is steady; then the deviatoric load is applied on the specimen by placing the whole setup in the compression testing machine and the data is acquired to plot the stress strain curve.

\subsection{Data Acquisition Unit}

National Instruments (NI) 10 channel strain indicator with data acquisition system using LAB VIEW software is used to record the strain and load at different intervals of time. Strain gauge and Load cell are attached to highly sophisticated computer to record data from which the necessary results can be tabulated.

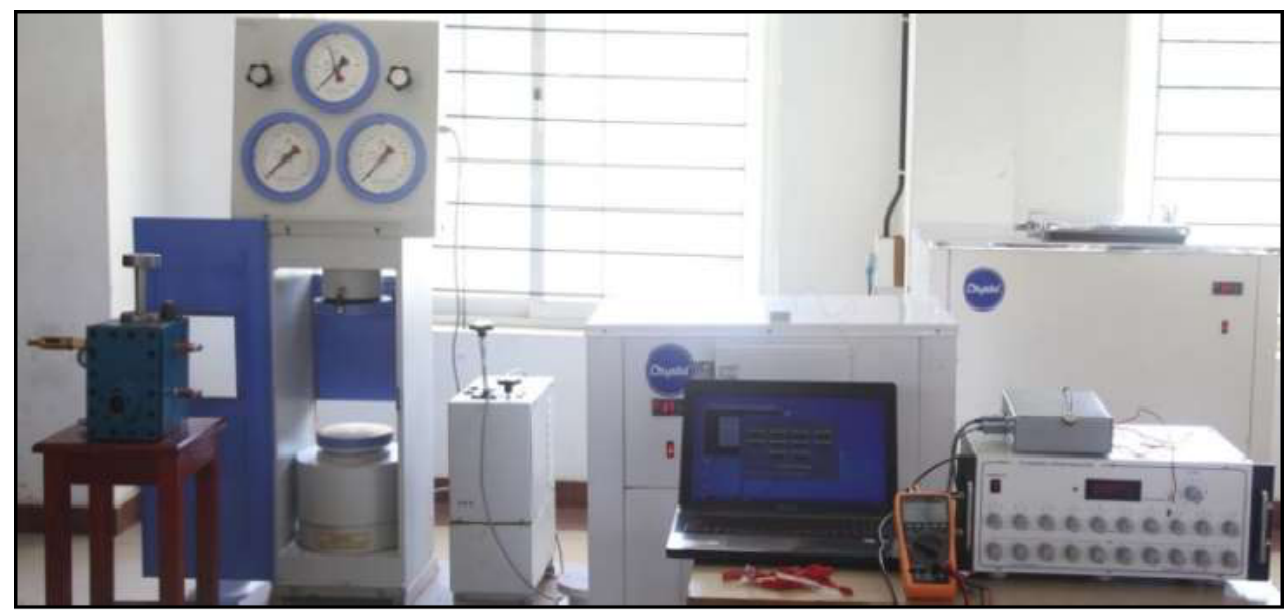

Figure 2 Laboratory triaxial test setup for frozen soil 


\section{TESTING PROCEDURE}

A cohesive type of soil was basically preferred for the study as the inter-particular attraction between the soil grains is higher and thus the prepared specimen will have adequate strength and stiffness in the frozen state [11]. Properties of the soil sample used is given in Table 1. Properties are obtained by performing initial test on the soil specimen.
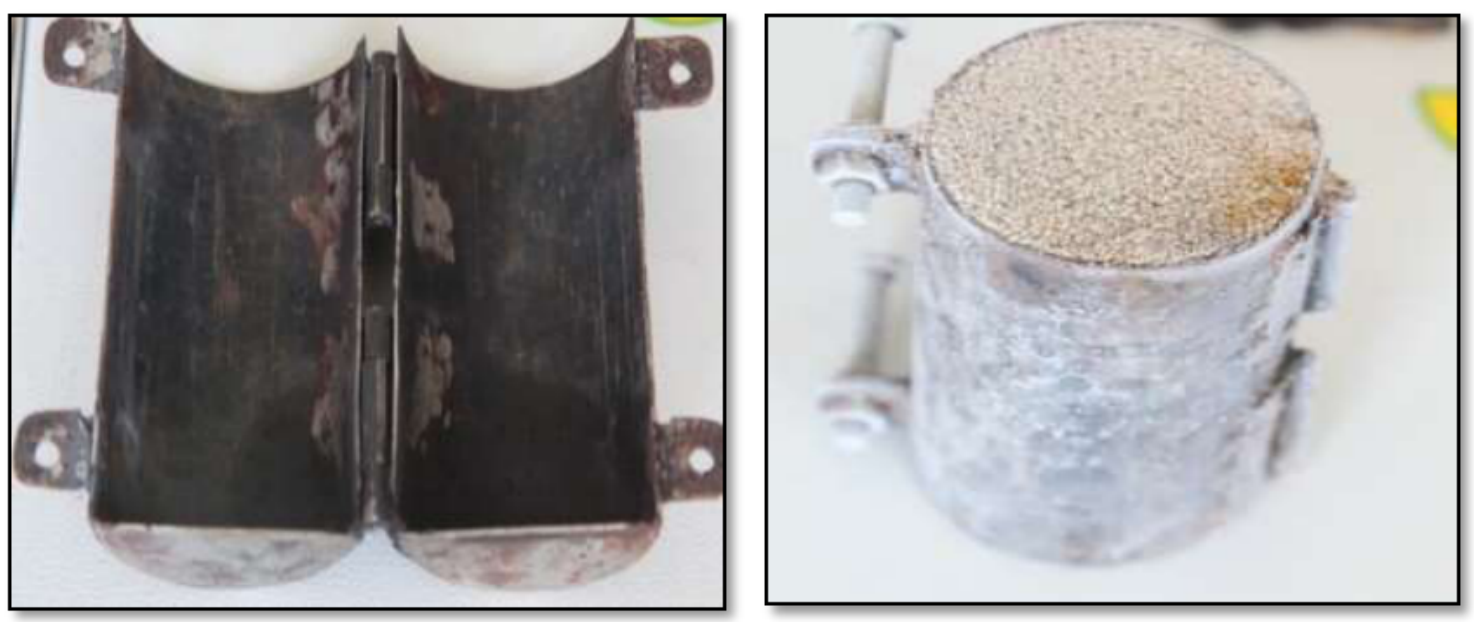

Figure 3 Moulds for the samples

Table 1 Physical properties of soil

\begin{tabular}{|c|c|}
\hline \multicolumn{2}{|c|}{ PHYSICAL PROPERTIES OF SOIL } \\
\hline Dry density $(\mathrm{g} / \mathrm{cc})$ & 1.36 \\
\hline Specific Gravity & 2.11 \\
\hline Moisture content $(\%)$ & 19.38 \\
\hline Permeability $(\mathrm{cm} / \mathrm{s})$ & $2.30 \mathrm{E}-04$ \\
\hline Cohesion $(\mathrm{kPa})$ & 36.07 \\
\hline Angle of internal friction $\left({ }^{\circ}\right)$ & 4.89 \\
\hline
\end{tabular}

For the preparation of frozen soil sample, a split mould having $125 \mathrm{~mm}$ length and $62.5 \mathrm{~mm}$ diameter is used. The soil sample is first oven dried for 24 hours and after successful drying, required quantity of water is added to maintain the moisture content. Soil is then placed gently into the split mould and compaction is given to the soil layers by means of small vibratory table. Then soil sample along with the mould is kept in the deep freezer. The sample is kept in the freezer till the required temperature is attained [12]. For attaining $-30^{\circ} \mathrm{C}$, 72 hours of freezing is essential while for $-15^{\circ} \mathrm{C}$ only 24 hours is enough. In this study water content of $18 \%$ is used. The sample for testing is maintained at a temperature of $-15^{\circ} \mathrm{C}$ and $30^{\circ} \mathrm{C}$. Temperature should be maintained throughout the test for getting appropriate results [13].

In this study, a typical C- phi soil sample is investigated under specified water content, temperature and different confining pressures. Unconsolidated undrained (UU) triaxial compression tests were conducted on remoulded frozen soils samples to assess the improvement in soil strength and mechanical behaviour of frozen soil, according to ASTM D4083. UU test is better preferred for this study as it represents the in-situ conditions [14]. Axial load was applied under constant stress conditions under confining pressures of 100, 200 and $300 \mathrm{kPa}$, at temperature of $-30^{\circ} \mathrm{C}$ to define the shear strength parameters [15]. All the tests were done under temperature-controlled condition through proper insulation and it was continuously monitored. Testing procedure for the specimen is as follows: 
1. Initial physical properties and shear parameters are obtained using the basic test and values of $\mathrm{c}$ and phi are obtained using Mohr circles.

2. Sample is prepared in required proportion.

3. Freezing the specimen in a split mould to sub-zero temperature $\left(-15^{\circ} \mathrm{C}\right.$ and $\left.-30^{\circ} \mathrm{C}\right)$.

4. Chilling glycol (coolant used) freezing to sub-zero temperature.

5. Dressing the specimen with neoprene cover to fix the strain gauge.

6. The strain gauge and load cell are connected to the data acquisition system to capture the strain and the load.

7. The specimen is kept in the triaxial cell and the coolant is filled in the triaxial cell to apply the confining pressure.

8. Load is applied at uniform rate to the specimen using compression testing machine until the specimen fails.

9. Strain and loads at specified time interval are recorded using the data acquisition system.

10. Using Mohr circle, cohesion and angle of internal friction are calculated from the recorded values.

\section{RESULTS AND DISCUSSION}

Similar to other granular materials, the strength of frozen soils consists of two components, friction and cohesion. For unfrozen fine-grained soils, it can be approximately expressed by the Mohr-Coulomb criterion with the frictional component linearly proportional to the normal stress and the cohesion part independent of the normal stress. However, for frozen soils especially compressed within a large range of confining pressures, this encounters serious difficulties. Because of the influence of confining pressure on ice and unfrozen water film, the influence of the stress state on the strength of frozen soils needs to be considered on both components. To investigate and compare frozen and unfrozen soils, initially all the soil properties and parameters are obtained from unfrozen soil using convention test methods and it is given in Table 1.

\subsection{Stress vs Strain behaviour of Frozen Soils}

To investigate the effect of freezing on the mechanical behaviour of frozen soils, the soil specimens should be tested with the same confining pressure, void ratio, temperature and ice saturation. Fig 4 show the stress-strain behaviour of the frozen soils and unfrozen soils at $18 \%$ water content under temperature of $-15^{\circ} \mathrm{C}$ and $-30^{\circ} \mathrm{C}$ at constant confining pressure of 200 $\mathrm{kPa}$. $\mathrm{X}$ axis is plotted on logarithmic scale.

In the frozen soil, though at different temperature the maximum load soil can withstand is much higher as compared to the unfrozen which is clear from Fig 4. Maximum stress unfrozen soil can withstand is only $73.25 \mathrm{kPa}$ while frozen soil at $-15^{\circ} \mathrm{C}$ can withstand 204.99 $\mathrm{kPa}$, whereas frozen soil at $-30^{\circ} \mathrm{c}$ bears $235.26 \mathrm{kPa}$. This increase in shear strength is mainly due to the increase in internal friction caused by frozen ice crystal in the pores of soil. These ice crystals also provide additional cohesion between particles which results in added strength of soil particles. 


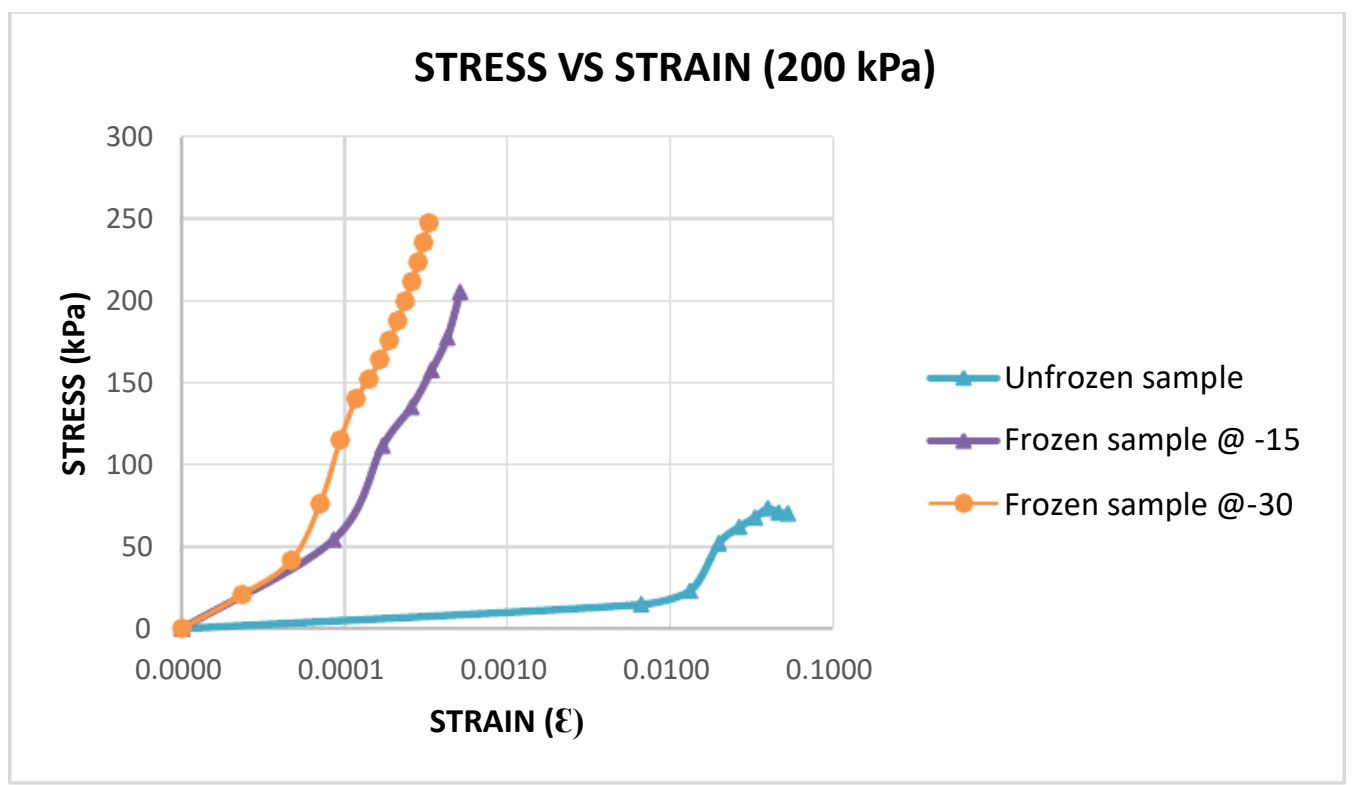

Figure 4 Stress vs Strain behaviour for $18 \%$ water content at $200 \mathrm{kPa}$

\subsection{Effect of Confining Pressure and Temperature on behaviour of Frozen Soils}

To study the effect of confining pressure on the behaviour of the frozen soils, tests were conducted at 3 different confining pressures of 100, 200 and $300 \mathrm{kPa}$ under constant temperature $\left(-30^{\circ} \mathrm{C}\right)$. Fig 5 and Fig 6 show the stress-strain behaviour of the frozen soils at the mentioned confining pressures. The shear strength increases with increase in confining pressure but after $200 \mathrm{kPa}$ it starts falling due to the melting of ice at higher pressures.

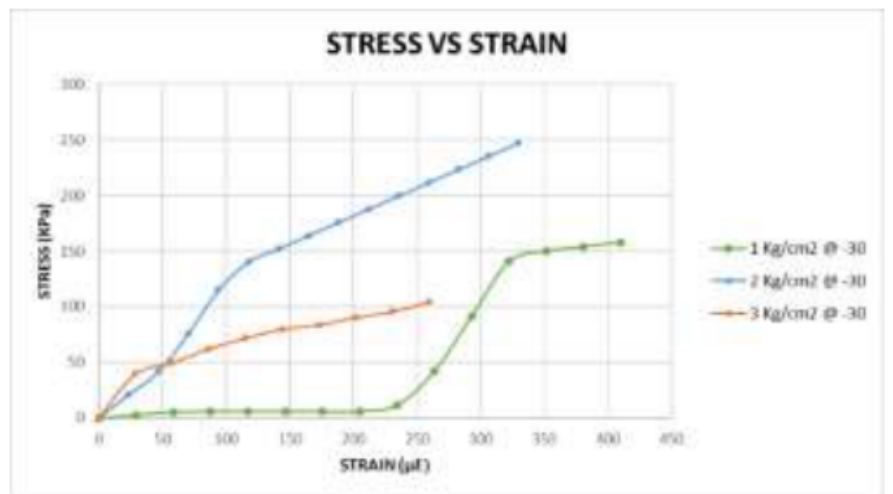

Figure 5 Stress vs Strain behaviour for different confining pressures at $-30^{\circ} \mathrm{C}$

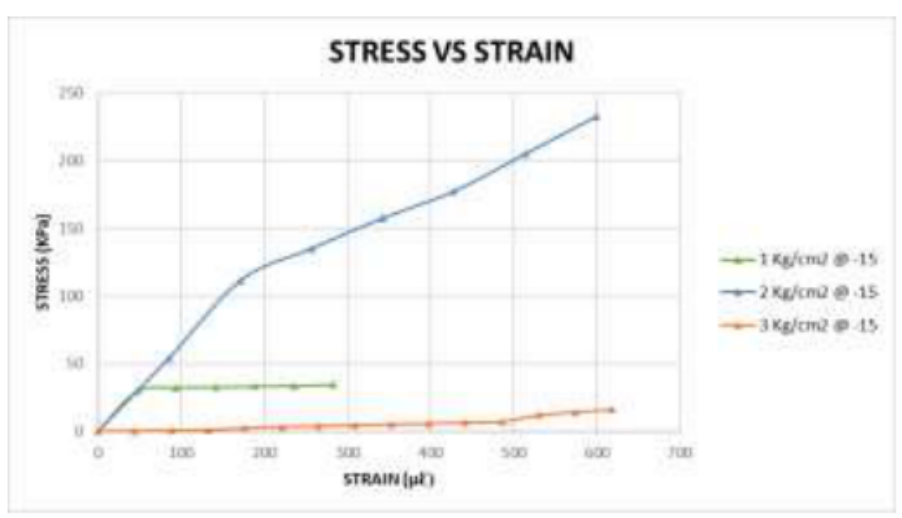

Figure 6 Stress vs Strain behaviour for different confining pressures at $-15^{\circ} \mathrm{C}$ 


\subsection{Effect of Shear Parameters on behaviour of Frozen Soils}

To study the effect of shear parameters on the behaviour of the frozen soils, tests were conducted at 3 different confining pressures of 100,200 and $300 \mathrm{kPa}$ under constant temperature $\left(-30^{\circ} \mathrm{C}\right)$ and constant water content of $18 \%$. The Mohr circle for the frozen and unfrozen soils are given in Fig 7, Fig 8 and Fig 9. The values of shear parameters obtained from these Mohr circles are given in Table 2. There is a significant increase in strength of soil at higher degrees of freezing temperature is evident. This is due to the added strength provided by the ice crystals forming in the pores of soils.

Table 2 shows the values of shear parameters obtained for the frozen soils at the mentioned confining pressures. The shear parameters values increase with increasing the confining pressure due to increase in shear parameters. This increase in shear strength can be utilized during the phases of excavation to prevent the collapse of soil.

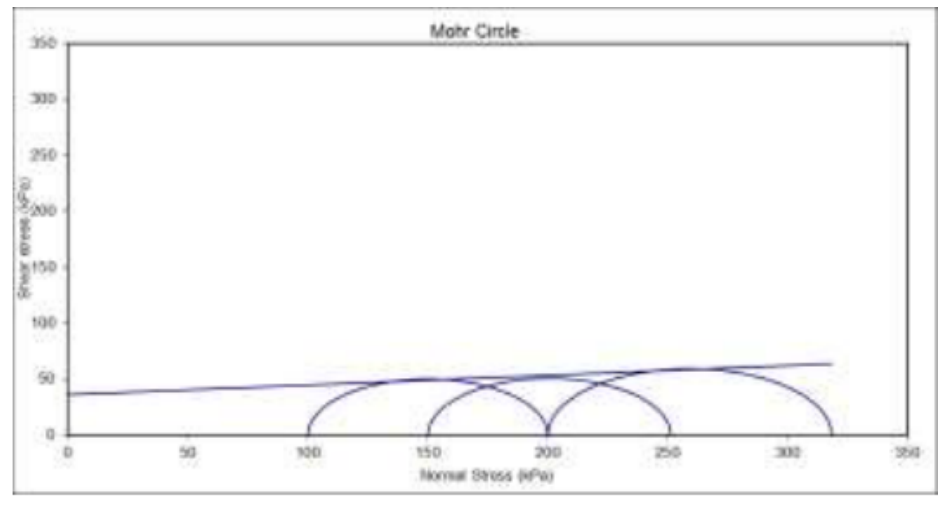

Figure 7 Mohr circle for unfrozen sample

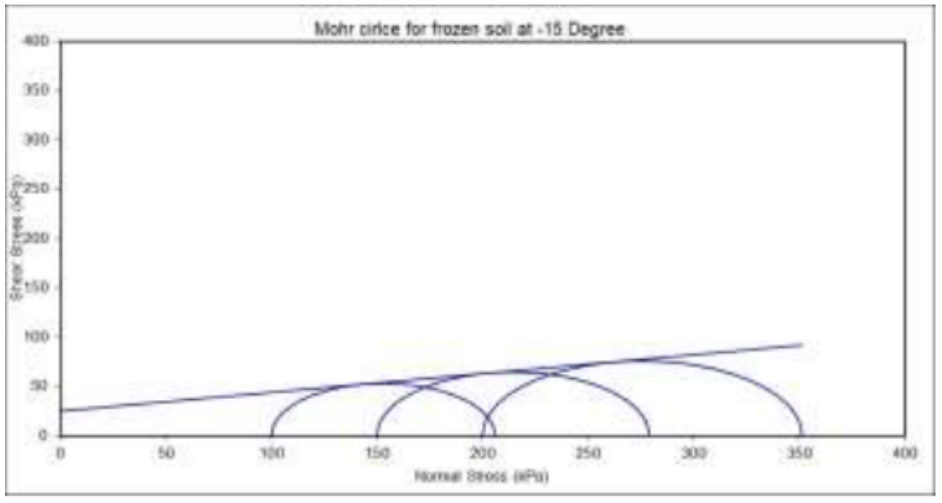

Figure $8 \mathrm{Mohr}$ circle for frozen sample at $-15^{\circ} \mathrm{C}$

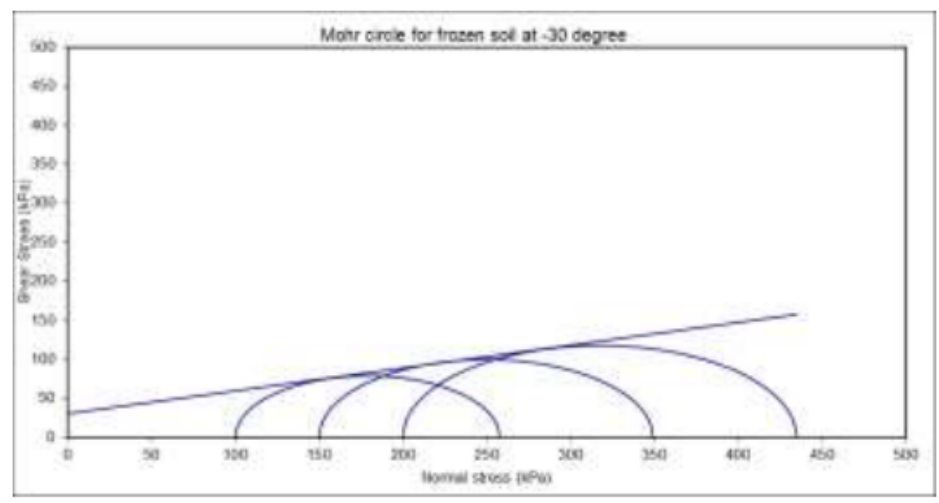

Figure $9 \mathrm{Mohr}$ circle for frozen sample at $-30^{\circ} \mathrm{C}$ 
Experimental Investigation on Shear Strength of Artificially Frozen C - Phi Soil

Table 2 Comparison of shear strength between unfrozen and frozen soils

\begin{tabular}{|c|c|c|c|}
\hline Properties & Unfrozen soil & Frozen soil (-15 $\mathbf{C}^{\mathbf{C}} \mathbf{)}$ & Frozen soil (-30 $\left.\mathbf{~} \mathbf{C}^{\mathbf{C}}\right)$ \\
\hline Cohesion $(\mathrm{kPa})$ & 36.07 & 25.13 & 30.67 \\
\hline Angle of internal friction $\left({ }^{\circ}\right)$ & 4.89 & 10.68 & 16.18 \\
\hline Shear strength $(\mathrm{kPa})$ & 44.64 & 45.13 & 76.52 \\
\hline
\end{tabular}

\section{CONCLUSION}

In this study, the effects of confining pressure and the stress-strain behaviour of frozen soil were examined and is compared with unfrozen soil sample to get an idea about the increase in strength acquired. A program of experiments was designed and conducted on soils. To ensure repeatability and comparability of the tests results, ice saturation, soil particle content and void ratio were kept constant. A special type of mould was designed and fabricated for curing the frozen samples. A triaxial compression apparatus for testing of frozen soils was designed and manufactured in the Geotechnical Laboratory. Triaxial compression tests were conducted on the frozen specimens. Strength is increasing significantly at higher temperatures but beyond a particular confining pressure strength drops suddenly. Sudden drop in strength is due to the melting of ice at higher confining pressures.

\section{REFERENCES}

[1] Esmaeili-Falak, M., Katebi, H., \& Javadi, A. Experimental Study of the Mechanical Behavior of Frozen Soils-A Case Study of Tabriz Subway. Periodica Polytechnica Civil Engineering, 62(1), 2018, 117-125.

[2] Li, H., Yang, H., Chang, C., \& Sun, X. Experimental Investigation on Compressive Strength of Frozen Soil versus Strain Rate. Journal of Cold Regions Engineering, 15(2), 2001, 125-133.

[3] Qi, J., \& Ma, W. A New Criterion for Strength of Frozen Sand under Quick Triaxial Compression Considering Effect of Confining Pressure. Acta Geotechnica, 2(3), 2007, 221.

[4] Zhang, S., Lai, Y., Sun, Z., \& Gao, Z. Volumetric Strain and Strength behavior of Frozen Soils under Confinement. Cold Regions Science and Technology, 47(3), 2007, 263-270.

[5] Yang, Y., Lai, Y., \& Chang, X. (2010). Laboratory and Theoretical Investigations on the Deformation and Strength behaviors of Artificial Frozen Soil. Cold Regions Science and Technology, 64(1), 39-45.

[6] Parameswaran, V. R., \& Jones, S. J. (1981). Triaxial Testing of Frozen Sand. Journal of Glaciology, 27(95), 147-155.

[7] Baker, T. H. W., Jones, S. J., \& Parameswaran, V. R. (1982). Confined and unconfined Compression Tests on Frozen Sands.

[8] Yao, X., Qi, J., Yu, F., \& Ma, L. (2013). A Versatile Triaxial Apparatus for Frozen Soils. Cold Regions Science and Technology, 92, 48-54.

[9] Sayles, F. H., Baker, T. H. W., Gallavres, F., Jessberger, H. L., Kinosita, S., Sadovskiy, A. V., \& Vyalov, S. S. (1987). Classification and Laboratory Testing of Artificially Frozen Ground. Journal of Cold Regions Engineering, 1(1), 22-48.

[10] Da Re, G., Germaine, J. T., \& Ladd, C. C. (2003). Triaxial Testing of Frozen Sand: Equipment and Example Results. Journal of Cold Regions Engineering, 17(3), 90-118.

[11] Li, H., Zhu, Y., Zhang, J., \& Lin, C. (2004). Effects of Temperature, Strain Rate and Dry Density on Compressive Strength of Saturated Frozen Clay. Cold Regions Science and Technology, 39(1), 39-45. 
[12] Xu, X., Lai, Y., Dong, Y., \& Qi, J. (2011). Laboratory Investigation on Strength and Deformation Characteristics of Ice-Saturated Frozen Sandy Soil. Cold Regions Science and Technology, 69(1), 98-104.

[13] Alkire, B. D., \& Andersland, O. B. (1973). The Effect of Confining Pressure on the Mechanical Properties of Sand-Ice Materials. Journal of Glaciology, 12(66), 469-481.

[14] Hu, X. D., \& Wang, J. T. (2013). The Triaxial Shear Test of Artificially Frozen Soils in Tunnel Construction of Hong Kong. In Applied Mechanics and Materials (Vol. 353, pp. 1653-1656). Trans Tech Publications.

[15] Li, D., \& Fan, J. (2018). A Study of Mechanical Property of Artificial Frozen Clay under Dynamic Load. Advances in Civil Engineering, Volume 2018, 8 pages. doi.org/10.1155/2018/5392641

[16] Prof. Dr. Mustafa B. Dawood And Reem Abd-Alraheem Nabbat, Flexural and Shear Strength of Non-Prismatic Reinforced High Strength Concrete Beams with Openings and Strengthened with NSM-CFPR Bars. International Journal of Civil Engineering and Technology (IJCIET), 6(9), 2015, pp 93-103

[17] Nagendra Prasad.K, Sivaramulu Naidu.D, Harsha Vardhan Reddy. M and Chandra.B, Framework for Assessment of Shear Strength Parameters of Residual Tropical Soils. International Journal of Civil Engineering and Technology (IJCIET), 4(2), 2013, pp 189207

[18] R. Deby Linsha, Y. Preethy Dharanya, V. Vinodhini and C. Pavithra, Improvement of Shear Strength of Soil Using Bitumen Emulsion. International Journal of Civil Engineering and Technology, 7(6), 2016, pp.156-165

[19] Brijesh Kumar, Nitish Puri and Saurabh Jaglan, Shear Strength Characteristics Of A Rockfill Material. Journal of Advanced Research in Engineering and Technology, 4(6), 2013, pp. 98-109

[20] R.K Kaushal, Rohit Yadav, Rohit Kumar and Shivam Gupta, Shear Strength Characteristics of Municipal Solid Waste. International Journal of Civil Engineering and Technology, 8(6), 2017, pp.1044-1053.

[21] G. Musalaiah, Bade Venkata Suresh, P. Srinivasa Rao and P. Govinda Rao. Shear Strength Enhancement in Vibratory Lap Welded Joints. International Journal of Mechanical Engineering and Technology, 8(1), 2017, pp. 160-168 